\title{
The legislative framework concerning family involvement in children's education
}

Diana-Crina Marin, Mușata Bocoş 


\title{
The legislative framework concerning family involvement in children's education
}

\author{
Diana-Crina Marin ${ }^{a *}$, Mușata Bocoş ${ }^{b}$ \\ ${ }^{a}$ Doctoral School "Educational, Reflection, Development", Babeş-Bolyai University, 7 Sindicatelor Street, 400029, Cluj-Napoca, Romania \\ ${ }^{b}$ Faculty of Psychology and Educational Sciences, Babeş-Bolyai University, 7 Sindicatelor Street, 400015, Cluj-Napoca, Romania \\ *Corresponding author: Diana.PANCU@ubbonline.ubbcluj
}

\section{Abstract}

Keywords: school-family partnership, Romanian primary educational system, family involvement, legislative framework
In order to understand the factors that significantly influence the quality of the school and family partnership, we have consulted some of the most important national and international legislative documents concerning the families' attributions in the process of raising and educating the children. We have discovered that each of these documents promotes the achievement of children's rights and values such as solidarity, tolerance, equal opportunities between boys and girls, mutual respect, positive attitudes, free access to compulsory education, permanent support for the families. The main responsibility of the parents is to provide the best living and educational conditions and to ensure the health of children. Each parent should offer financial, affective, cognitive and social support for their children. The legislative framework of Romania is in accordance with the international legislation and recommendations. The superior interest of the child should guide the actions of all the educational actors. Parents have the obligation to act as real partners of educational institutions and should be actively involved in their children's education. Teachers and family members have the responsibility to join their forces in order to maintain a high-quality cooperation and a constant and bidirectional communication. The legislation of Romania had a positive evolution and encourages the parents' participation in the process of decision making and in school life.
Schlüsselworte:

Partnerschaft

Schule-Familien, rumänische

Grundschulbildung, Familienbeteiligung an der

Kindererziehung,

Rechtsrahmen
Um die Faktoren zu verstehen, die die Qualität der Partnerschaft zwischen Schule und Familie maßgeblich beeinflussen, haben wir einige der wichtigsten nationalen und internationalen gesetzlichen Bestimmungen über die Aufgaben von Familien in dem Prozess der Erziehung und Bildung von Kindern analysiert. Wir haben festgestellt, dass jede dieser Bestimmungen die Gewährung der Rechte von Kindern sowie Werte wie Verbundenheit, Toleranz, Chancengleichheit für Jungen und Mädchen, gegenseitigen Respekt, positive Einstellungen, freien Zugang zum Pflichtschuluntericht und dauerhafte Unterstützung für Familien fördert. Die grundsätzliche Verantwortung der Eltern ist es, die besten Lebens- und Bildungsbedingungen zu bieten und für die Gesundheit der Kinder zu sorgen. Jeder Elternteil muss seinen Kindern finanzielle, affektive, kognitive und soziale Unterstützung bieten. Der rumänische Rechtsrahmen entspricht den internationalen Rechtsvorschriften und Empfehlungen. Das beste Interesse des Kindes sollte das Handeln aller Bildungsakteure leiten. Die Eltern sind verpflichtet, als echte Partner der Bildungseinrichtungen zu agieren und sollten aktiv in die Bildung ihrer Kinder einbezogen werden. Die Lehrer und die Familienmitglieder tragen die Verantwortung, ihre Kräfte zu bündeln, um eine qualitativ hochwertige Zusammenarbeit und eine ständige und bidirektionale Kommunikation aufrechtzuerhalten. Die rumänische Gesetzgebung hat sich positiv entwickelt und ermutigt die Eltern, am Entscheidungsprozess und am Schulleben teilzunehmen.

\section{Introduction}

The actual legislative framework contains provisions regarding the cooperative relationship that should be established between schools and families. Considering that the positive evolution of students during the entire period of their studies is necessary, it is important to understand all the factors that can influence their school results. The national legislative framework of Romania contains provisions regarding the way that families and school should cooperate. At the same time, understanding of the international provisions regarding school-family partnership is very important for each person who works with the children. The purpose of this study is to summarize the most important legislative provisions regarding the school-family partnership

\section{Theoretical foundation}

A constant and high-quality involvement in children's education at home and at school and an effective communication between schools and families influences in a positive manner the school evolution of the children (Fantuzzo, Gadsden, Sproul, McDermott, Hightower \& Minney, 2013; Fantuzzo, McWayne, Perry, \& Childs, 
2004; Jeffries, 2012, Fisher, 2009). Recommendation no. 1501/ 2011, published by the Parliamentary Assembly of the Council of Europe, contains relevant information about the significant impact of school and families in children's development and education. On the one hand, the family is considered an educational institution which is responsible for raising and educating the children. On the other hand, the school provides formal learning contexts, relevant for the harmonious development of each child. The vision through only one of the institutions is considered responsible for the children's success at school is considered wrong and with negative effects on the quality of the school and family partnership.

According to Răduţ-Taciu, Bocoş, Chiş (coord.) (2015), the main functions of the family are the following: the biological function, the educational function, the socioemotional function, the economic function, and the legal function. Stăiculescu (2011) states that the school-family partnership is guided by the actual legislative framework. Joint efforts of school, family, and communities are necessary in order to offer to each student relevant learning opportunities, according to their educational interest and learning needs.

Romanian legislation regarding school-family partnership sets out obligations and rights of each educational part. Romania's Law of National Education (Law no. 1/ 2011) encourages the creation of genuine partnerships between school and family. Transparency of decisions and results, bidirectional communication, and support for parents are some of the directions of action suggested in order to increase parents' participation in school's life. The Romanian legislation on children's protection and education had a positive evolution
(Rădulescu, 2011). The educational system of Romania is facing real problems, despite the continuous efforts and reforms applied over the last years. In this context, we consider that research concerning the effective strategies to strengthen the school-family partnership should be continued.

\section{Research methodology}

Our investigation was oriented towards the following research question: "What are the most relevant legislative provisions that parents, and teachers should take into consideration in the education process of the children?" The answer to this question helps us to better understand the parents' and teachers' obligations in order to maintain an effective and strong cooperation between schools and families.

In the process of selection of the relevant legislative national and international documents we have used the following premises:

- legal provisions should be applicable to the primary educational level;

- documents should be part of the Romanian legislative framework or should be relevant international legal instruments as treaties, conventions, charts, declarations, and recommendations.

Table no. 1 contains a list of some of the most relevant international legislative documents regarding the school and family responsibilities concerning children's education. Some of these documents were included in the legislative framework of our country.

Table no. 1. Important legislative documents and provisions regarding the responsibility of the school and the family in regard to children's care and education

\begin{tabular}{c} 
Document's name \\
\hline Universal Declaration of Human Rights (1948) \\
Convention on the Rights of the Child (1989) \\
World Declaration on Education For All (1990) \\
The Salamanca Statement (1994) \\
European Convention on the Exercise of Children's \\
Rights (1996) \\
The Revised European Social Charter (1996) \\
Recommendation 1286 adopted by the Parliamentary \\
Assembly of the Council of Europe (1996) \\
Convention 182 on The Worst Forms of Child Labour \\
(1999) \\
Charter of Fundamental Rights of the European Union \\
United Nations Millennium Declaration (2000)
\end{tabular}

Examples of important legislative provisions

$\checkmark \quad$ Free access to compulsory education and support throughout the period of studies;

$\checkmark$ Parents' responsibility to take educational decisions in the interest of their children, including the ones regarding the type of education that shall be given to them;

$\checkmark$ Parents' and educators' obligation to ensure the necessary factors for the full development of children;

$\checkmark$ Obligations concerning the respect for the children's rights and their fundamental freedoms; 
Recommendation 1501 adopted by the Parliamentary

Assembly of the Council of Europe (2001)

A world fit for children (Resolution adopted in 2002 by the General Assembly of the United Nations)

Convention on Contact concerning Children (2003)

Recommendation 19 adopted by the Parliamentary

Assembly of the Council of Europe (2006)

The Treaty of Lisbon (2007)

The 2030 Agenda for Sustainable Development (2015) $\checkmark \quad$ The responsibility of both parents regarding the care and education process of the children;

$\checkmark \quad$ Creating effective school-family-community partnerships in order to offer the best educational opportunities and learning contexts for each child;

$\checkmark \quad$ Ensure the factors for a good health and start in life for each child, financial support, protection and positive socio-emotional climate.

The main responsibilities of the teachers are included in their individual employment contract and are mentioned in their job descriptions. The content of the documents complies with the content of Romania's Law of National Education (Law no. 1/ 2011) and the Framework Regulation for the Organisation and Functioning of the Secondary School Units approved by Order no. 5079/31.08.2016 issued by the Minister of National Education. Table no. 2 includes a list of the most important responsibilities of the parents in the education and development process of children, based on the content of the national legislative framework.

Table no. 2. Responsibilities and duties of parents concerning the development of children

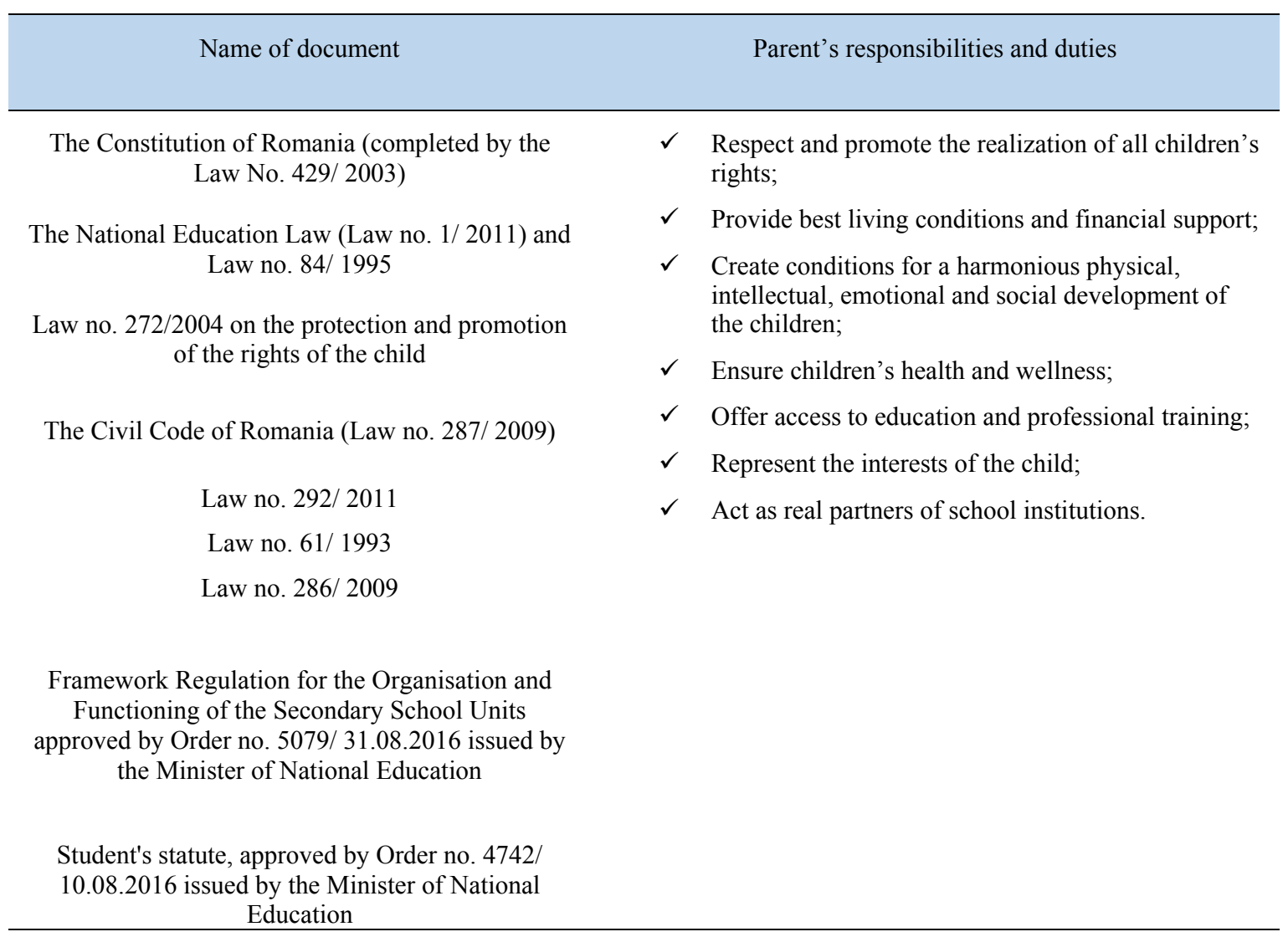

\section{Results}

For the purpose of highlighting the modifications of the legislative framework in Romania, concerning the schoolfamily partnership, we have consulted the Law no. 84/1995 and the Law no. 1/ 2011, as amended. The results of this diachronic study were included in Table no. 3. The actual Law of National Education in Romania encourages the parents' participation in children's education and in school life. Between the educational institutions and the families 
should be signed a contract, which lists the rights and obligations of each of the educational agents (see the article 86 from the Law no. 1/ 2011).

Table no. 3. Comparative analysis between the contents of actual and of the old version of the Law of National Education

\begin{tabular}{ll}
\hline Common provisions & Distinctive contents \\
\hline
\end{tabular}

Parents or legal representatives of students have:

the obligation to ensure the school frequency during the compulsory education;

the right to be actively involved in the process of decision making concerning the education of their children.
The Law of National Education, Law no. 1/ 2011 has the following characteristics:

- $\quad$ highlights the importance of the active involvement of parents in children's education (Article 3 (q));

- $\quad$ establishes the obligation of signing a contract between the school and the family, which includes the right and the duties of each of the educational partners;

- $\quad$ highlights the importance of total transparency in the process of decision making and the communication of the results obtained.
In 2018 the Ministry of Education in Romania proposed for public debate the draft of the project of a national strategy concerning the parental education. In July, the Minister decided not to assume the content of this document. The draft of the strategy was resent to the initiators for modifications because of the negative feedback received. We consider that a national strategy in the domain of school-family partnership is welcomed if its content is accepted by all the social partners. The content of the educational activities should be in accordance with the parents' and future parents' interests and training needs. At present, formal institutions of education, medical centres, and social assistance centres are the main institutions which offer assistance and support for parents for improving their knowledge and abilities.

\section{Discussions}

During this study legislative documents have been consulted in regard to parents' and schools' responsibilities concerning the children's development. The legislation in Romania is in accordance with the values promoted by the international legislative framework. The actual legislative framework in Romania promotes the achievement of all children's rights, facilitate parents' participation in the educational process, and encourage the consolidation of the school-family partnership. Future studies should be focused on understanding the legislative framework concerning the children with special educational needs. At the same time, we should pay attention to the legislative context concerning children in special situations, like the ones in foster care or in adoption.

\section{Conclusions}

All legislative instruments that we have consulted establish the rights and responsibilities of parents concerning the care, protection and education of children. Some of the responsibilities of the parents were not directly presented but resulted from the content of the articles. Some of the documents or parts of them are no longer valid or actual but were analysed in order to better understand the evolution of the legal framework concerning the duties of parents and school representatives in children's development and education. 


\section{Authors note:}

Diana-Crina Marin is currently a teacher at Liceul Teoretic "Pavel Dan" Câmpia Turzii ("Pavel Dan" Theoretical High School of Câmpia Turzii) and Doctoral Student at Babeș-Bolyai University. Her research areas are aimed at discovering innovative modalities to consolidate the school-family partnership, considering that the school and family should be real partners in children's education. She is also interested in finding the most efficient teaching practices that could be successfully used in the educational process.

Mușata Bocoş is University Professor and Ph.D. Coordinator at the Faculty of Psychology and Sciences of Education (Babeș-Bolyai University, Cluj-Napoca, Romania). She has obtained a Ph.D. in Educational Sciences in 1997 at Babeș-Bolyai University. Her research interests are reflected in a series of studies and articles published in important national and international journals. Her teaching activity covers several domains such as the theory and methodology of curriculum, general didactics, and educational research.

\section{References}

Fantuzzo, J., Gadsden, V., Li, F., Sproul, F., McDermott, P., Hightower, D., \& Minney, A. (2013). Multiple dimensions of family engagement in early childhood education: Evidence for a short form of the Family Involvement Questionnaire. Early Childhood Research Quarterly, 28, 734-742.

Fantuzzo, J., McWayne, C., Perry, M. A., \& Childs, S. (2004). Multiple Dimensions of Family Involvement and Their Relations to Behavioral and Learning Competencies for Urban, Low-Income Children. School Psychology Review, $33,467-480$.

Jeffries, K. (2012). Increasing parental involvement in early childhood education. (Doctoral Thesis). Retrieved from http://scholarcommons.usf.edu/etd/4340. University of South Florida.

Fisher, Y. (2009). Defining parental involvement: The Israeli case. US-China Education Review, 6, 33-45.

Răduț-Taciu, R., Bocoș, M.-D., Chiş, O. (coord.). (2015). Tratat de management educațional pentru învățământul primar și preșcolar. Piteşti: Editura Paralela 45.

Stăiculescu, C. (2011). Școala și comunitatea locală. Parteneriat pentru educație. București: Editura ASE.

Rădulescu, S. (2011). Evoluţia legislaţiei în domeniul protecţiei şi asistenţei sociale a copilului în România. Revista Română de Sociologie, 3-4, 257-280.

Recommendation 1501 (2001). Retrieved from $\mathrm{http} / / /$ assembly.coe.int/nw/xml/XRef/Xref-DocDetailsEN.asp?FileID $=16877 \&$ lang $=\mathrm{EN}$. 